\title{
Angiogenesis, haemostasis and cancer: new paradigms and old concerns
}

\section{Angiogênese, homeostasia e câncer: novos paradigmas e velhos problemas}

Maria Duarte'; Adhemar Longatto Filho ${ }^{1,2}$; Fernando C. Schmitt ${ }^{3}$

key words

Angiogenesis

Lymphangiogenesis

FGF

Thrombin

\section{abstract}

Neovascularization is a crucial phenomenon for the continuous growing of neoplastic cells and cancer progression. The growth of new blood vessels from pre-existing vessels (angiogenesis) occurs in several physiological and pathological conditions, including cancer, where it is critical for tumor-cells nutrition. Recently, new remarkable insights regarding angiogenesis and blood coagulation (key events in vascular biology) have been described. The serine protease thrombin, which plays a central role in blood coagulation cascade through its ability to cleave fibrinogen conducting to fibrin clot formation, is also known to be involved in embryogenesis, inflammation, wound healing, through its active role on vascular remodeling. Although the increased knowledge of factors regulating angiogenesis and coagulation led to the understanding that angiogenesis, homeostasis and carcinogenesis are three close team players, little is still known about how these pathways support each other in the process of angiogenesis in vivo. This review summarizes current understanding of blood coagulation cascade role in conducting angiogenesis and tumor progression, as well as provides an overview of the emerging anti-angiogenic and anti-coagulation therapies inducing tumor regression.

\section{resumo}

A neovascularização é um processo fundamental para a sobrevivência e a progressão das células neoplásicas malignas. O crescimento de novos vasos sanguíneos a partir de vasos já existentes, fenômeno designado como angiogênese, está envolvido em vários processos fisiológicos e patológicos, incluindo o crescimento tumoral, onde a angiogênese desempenha papel crítico na nutrição das células tumorais. Tal como a angiogênese, o sistema de coagulação sanguínea exerce importante função na biologia vascular. A trombina, uma serina protease, tem papel fundamental na cascata de coagulação, pela quebra enzimática do fibrinogênio e pela conseqüente produção de fibrina. Essa protease encontra-se também implicada em desenvolvimento embrionário, inflamação e cicatrização, processos nos quais a remodelação vascular está altamente ativa. Apesar de o crescente conhecimento de fatores reguladores da angiogênese e da coagulação demonstrar que a carcinogênese, a coagulação e a angiogênese são três close team players, ainda muito pouco se sabe sobre o modo como esses players comunicam-se e interagem no processo de angiogênese in vivo. Esta revisão sumariza os conhecimentos atuais quanto ao papel da cascata de coagulação na condução do processo angiogênico e do crescimento tumoral, bem como oferece uma visão geral sobre recentes terapias antiangiogênicas e anticoagulantes envolvidas na regressão tumoral.

\section{unitermos}

Angiogênese

Linfangiogênese

FGF

Trombina

1. PhD, Life and Health Sciences Research Institute, School of Health Sciences, Universidade do Minho, Braga, Portugal. 


\section{Introduction}

During embryonic vasculogenesis, blood vessels are formed from endothelial cell (EC) precursors angioblasts -, which assemble into a primary capillary plexus. This primitive network then differentiates, and new blood vessels sprout and branch from pre-existing capillaries during the process of angiogenesis, being stabilized by mural cells (pericytes in medium-sized and smooth muscle cells [SMC] in large vessels), which then regulate EC proliferation, survival, migration, differentiation, vascular branching, blood flow and vascular permeability ${ }^{(2,4)}$ (Figure 1).

Blood vessels run through virtually every organ in the body (except the avascular cornea and the cartilage), assuring metabolic homeostasis by supplying oxygen and nutrients and removing waste products. Therefore, angiogenesis is known to be essential in several physiologic processes, such as organ growth and development, wound healing and post-ischemic tissue repair ${ }^{(16,52)}$. Under these circumstances, angiogenesis occurs in a highly regulated manner whereby pro-angiogenic factors stimulate a phase of rapid migration, proliferation, followed by a phase of vessel differentiation and maturation of ECs. Eventually, the endothelium monolayer becomes quiescent and a local balance of pro- and anti-angiogenic factors tightly regulates the whole process. The moment in which this "normal" balance is disrupted mediates the "angiogenic switch"(20) towards pathological angiogenesis, in the course of process, such as tumor growth and metastasis, rheumatoid arthritis, diabetic retinopathy, and psoriasis ${ }^{(16,45,54,68)}$. This switch clearly involves more than simple upregulation of angiogenic activity and is known to be the result of net balance between positive and negative regulators.

There are three particularly important stimulators of angiogenesis: i) vascular endothelial growth factor $\left(\right.$ VEGF) ${ }^{(14,53)}$; ii) fibroblast growth factor (FGF) ${ }^{(33,59)}$; iii) angiopoetins $(\mathrm{Ang})^{(9,36)}$; between many others, like plateletderived growth factor (PDGF), epidermal growth factor (EGF), ephrins ${ }^{(22)}$; transforming growth factors alpha and beta (TCF- $\alpha$ and $-\beta$ ), interleukins, chemokines, and small molecules, such as sphingosine 1-phosphate ${ }^{(51)}$, that are known to promote cell proliferation, survival and differentiation of $\mathrm{ECs}^{(56,60)}$. For a general overview of the different molecular players involved in the angiogenesis process, see Figure 1.

\section{Vascular endothelial growth factor}

Initially identified for its ability to mediate vascular permeability, VEGF was later found to be a mitogen agent for $\mathrm{ECs}^{(31,58)}$. Today VEGF is recognized as an essential cytokine for the development and homeostasis

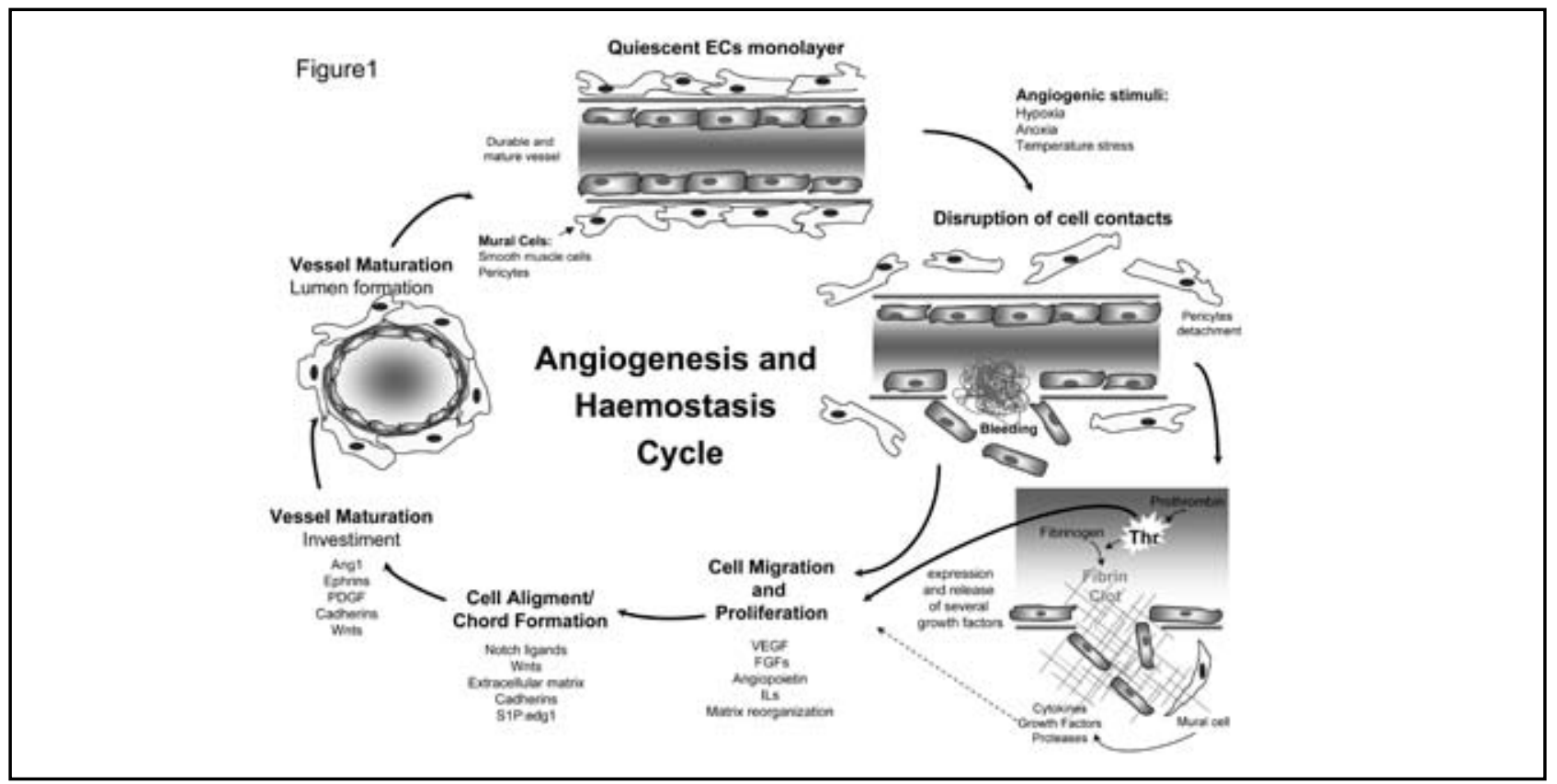

Figure 1 - Angiogenesis and homeostasis cycles. In response to an angiogenic stimulus, the endothelial cell contacts are disrupted, triggering the blood coagulation cascade, in which several proteases are activated. Thrombin-induced signaling in the endothelium results in multiple phenotypic changes, as well as expression and release of several different molecules, known to play a crucial role as angiogenic stimulators, contributing to cell migration and proliferation, cell alignment and tubule formation, and the maturation of vascular structures into vessels by investment with mural cells, which can either be pericytes, in the case of small vessels, or smooth muscle cells, in the case of larger ones. All these steps lead to the formation of a continuous lumen with flow. Factors which control the various steps are listed 
of cardiovascular systems. Inactivation of a single VEGF allele results in embryonic lethality at mid-gestation due to severe cardiovascular defects ${ }^{(5,13)}$. The biologic activities of VEGF are mediated principally by two related cell surface receptors, VEGFR1 and VEGFR2, with extracellular ligandbinding domains and intracellular protein-tryrosine kinase domains $^{(44)}$. Although the role of VEGFR1 remains a little bit controversial, the activation of VEGFR2 has been shown to promote differentiation of progenitor's cells, migration, mitogenesis, survival, nitric oxide release, and vascular permeability ${ }^{(26,39,70,72,74)}$. While neonatal mice expression of VEGF is required for survival(18), the function of VEGF signaling in adult vessels is less clear. There is evidence that activation of this signaling pathway is required for the maintenance of fenestrations in certain vascular beds ${ }^{(11)}$. Blockage of VEGF signaling in adult mice has resulted in reduced capillary density and proteinuria.

\section{Fibroblast growth factor}

The family of FGFs comprises 24 structurally related members, acting in concert with heparin sulphate proteoglycan to mediate a great variety of cellular responses through binding and activation of four receptor tyrosine kinase, the fibroblast growth factor receptors (FGFRs) ${ }^{(24)}$. FGF1, the founding member of the FGF family, is able to influence each critical stage of angiogenesis, including EC detachment, migration, proliferation, and ultimate differentiation into a functional capillary vessel ${ }^{(50,57)}$. Within extracellular matrix degradation, FGF1 is involved in the upregulation of urokinase plasminogen activator (UPA) and matrix metalloproteases (MMPs), and expression modulation of UPA receptor on the EC surface, thus allowing the localization of the proteolytic activity at the leading edge of the cell at the front of migration ${ }^{(38)}$. FGFRs are crucial patterns of FGF-induced angiogenesis, FGFR1 null embryos are developmentally retarded and dye during gastrulation ${ }^{(71)}$, however expression of a dominant negative form results in a significant impairment of blood vessel development ${ }^{(30)}$. It has recently been demonstrated that FGFR1 and FGFR2 carry distinct roles in regulating cell survival, thus while FGFR1 induced cell survival, FGFR2 activation promoted cell apoptosis, suggesting that they may play distinct roles within the same cell context ${ }^{(69)}$. Interestingly, an intimate crosstalk seems to exist between FGF2 and different members of the VEGF family during angiogenesis, lymphangiogenesis, and vasculogenesis, underlying the complexity of angiogenesis, a regulated mechanism, where each phase of the angiogenic cycle is highly regulated.

\section{Angiopoetins: tie signaling axis}

Ang1 belongs to a family of ligands currently comprising four members ${ }^{(9)}$. From these, Ang1 and Ang2 are more understood with respect to their roles in developmental and pathological angiogenesis. Although these two ligands bind to the receptor tyrosine kinase Tie2 with similar affinities, Ang2 can inhibit Ang1 under some specific physiological contexts ${ }^{(36)}$. In adult settings Ang1 is a natural anti-permeability factor, protecting against excessive plasma leakage, since it contributes to stabilization of preexisting vessels or maturation of newly formed ones by the recruitment of pericytes and SMCs ${ }^{(63)}$. On the other hand, Ang2 can either be involved in the regression or the formation of new blood vessels, since this angiogenic factor has the capacity to block its receptor (Tie2), promoting either the regression or the sprouting of vessels, depending on VEGF presence. Thus Ang2 is preferentially expressed at angiogenic and vascular remodeling sites, enabling exit, migration and proliferation of $\mathrm{EC}$, or its regression during the process of angiogenesis ${ }^{(36,49)}$.

Endogenous inhibitors of angiogenesis include hormone metabolites, and apoptosis modulators ${ }^{(16)}$. Curiously, many inhibitor molecules, such as "statins", are derived from larger proteins that have no effect on angiogenesis ${ }^{(46)}$. Among those is angiostatin ${ }^{(48)}$, a fragment of plasminogen that binds directly to adenosine triphosphate synthase on the surface of ECs, which might play a role in intracellular acidifications triggering apoptotic events in $\mathrm{EC}^{(41)}$. Other anti-angiogenic proteins resulting from proteolysis of larger molecules are endostatin (a fragment of collagen XVIII) ${ }^{(47,61)}$, tumstatin $^{(34)}$, and canstatin (fragments of collagens that bind to integrins) $)^{(27)}$. Some full-length extracellular proteins also display anti-angiogenic activity. Among them are thrombospondin-1, -2, and -3, produced by normal fibroblasts ${ }^{(19)}$; interferon alpha, produced by leucocytes ${ }^{(55)}$; and platelet factor $4^{(35)}$.

The haemostatic system (or coagulation cascade), which coordinates the cessation of blood loss from damaged vessels, regulating platelets adherence and fibrin formation, is normally inactive in adults due to a balance between proand anti-coagulant proteins present in the blood stream. In recent years, it has become increasingly evident that the blood coagulation system represents a major regulatory tool in vascular development. Indeed, the EC surface, which is the area of contact between the fluid blood compartment and the vessel wall, is the site where coagulation cascade conducts its activity, especially when the endothelium is injured or denuded. Under these circumstances, the 
permeability of the damaged vessel is augmented, resulting in the extravasation of fibrinogen and fibronectin and the formation of the fibrin clot that acts as temporary scaffold for migrating ECs. Resolution of venous thrombus involves the formation of vascular channels within the thrombus and new blood vessels, contributing to restoration of blood flow $^{(67)}$. These events result in migration of proliferating ECs into fibrin mesh in order to repair the vessel wall and in the further adhesion and spreading of ECs, leading to the understanding that angiogenesis and coagulation systems are closely interconnected (Figure 1).

\section{Angiogenesis, haemostasis and carcinogenesis: how do they link?}

Blood vessels neovascularisation not only allows for the continued growth of the primary tumor, but also provides migrating tumor cells access to the systemic circulation, facilitating metastisation. The involvement of vascular system in tumor growth obviously encompasses angiogenesis, and induces also systemic hypercoagulability and a prothrombotic state. The haemostatic system, as already mentioned, is normally inactive in adults. The response to a vascular injury is considered to begin after disruption of the vessel wall and exposure of tissue factor (TF), which is involved in process of tumor growth, angiogenesis, and metastasis ${ }^{(32)}$. Interestingly, certain genetic events directly associated to tumorigenesis, like expression of Kirsten rat sarcoma viral oncogene homolog (K-ras), epidermal growth factor receptor (EGFR), phosphatase and tensin homologue (PTEN) or p53 mutants, have been demonstrated to lead to an increase in TF levels, as well as its activity. Therefore, they promote tumor aggressiveness, angiogenesis, and hypercoagulability, originating thrombin in the surrounding environment, which will then lead to platelet activation, being accompanied by important physical, biological, and biochemical events. Procoagulant phospholipids (phosphatidylserine) are then exposed, as binding sites that allow assembly of coagulation proteins on the platelet's outer leaflet, conducting to a burst of thrombin generation. The sustained generation of serine protease thrombin, for example, at sites of thrombosis, has focused attention on vascular remodeling in response to thrombosis, as well as other vascular injuries. This serine protease has also been shown to degrade various constituents of basement membranes, and thus may facilitate cell invasion and increase the metastatic potential of neoplastic cells. Experiments conducted by Tsopanoglou and Maragoudakis several years ago demonstrated that a brief exposure (less than 15 minutes) of ECs to thrombin causes a marked inhibition of their ability to adhere to type IV collagen and laminin, suggesting that thrombin enables ECs to detach from their anchorage site on the basement membrane of the neighboring vessel, to survive without attachment to the extracellular matrix and allowing their migration to distant sites ${ }^{(65)}$. Complementary, the role of bone marrow (BM) cells in angiogenesis, vascular regeneration, tumor formation, and thrombus recanalization has been extensively documented ${ }^{(40)}$, what requires mobilization of progenitor cells into circulation, recruitment at the target site, and further expression and differentiation into appropriate cell types. Tarzani et al. have demonstrated that thrombin promotes BM cells proliferation and endothelial cell progenitors differentiation into $\mathrm{ECs}^{(62)}$, in a mechanism mediated by protease-activated receptor (PAR) 1 activation, a major thrombin G-protein coupled receptor ${ }^{(66)}$. These noteworthy findings may have important implications for the role of coagulation factors, particularly thrombin, in BM progenitor cell biology. Thus, in addition to modulating pre-existing vascular cells, thrombin may also impact repair mechanisms and angiogenesis by affecting BM-derived progenitor cells to proliferate and differentiate.

The premalignant role of thrombin in tumor adhesion, growth, metastasis, and angiogenesis is well recognized, and in general correlated with overexpression and activation of PAR1. There are emerging evidences that PAR1 modulates cell proliferation and motility in physiophathologic cell invasion process, suggesting its role in the setting of cancer growth and metastasis. Indeed, the involvement of PAR1, which can be activated by thrombin, in the invasive and metastatic processes is known for different tumors, like breast, melanoma, and colon cancer ${ }^{(8,12,15,28)}$. The molecular mechanisms underlying PAR1induced tumor invasion remain to be elucidated, and possible hypotheses, including the involvement of different players like growth factors and cytoskeleton-related proteins, which will promote cellular growth and cytoskeleton reorganisation, need urgently to be addressed.

Thrombin through PAR1 activation is known to modulate the expression of several mitogen factors, including PDGF, FGF2, and VEGF, well-known pro-angiogenic factors ${ }^{(1,3,6,7)}$. We recently found that thrombin, through PAR 1 activation, is also able to induce the expression and the release of FGF1, a potent mitogen for different cell types, and a wellknown angiogenic factor ${ }^{(10)}$, linking haemostasis to the neovascularisation process, most probably in both normal and abnormal context. 
Thus, several angiogenic players are shared and/or activated by haemostasis, conducting to the idea that during the process of tumor growth, angiogenesis as well as haemostasis processes can serve as "feeder" sources, allowing the growth and survival of tumor cells, and its further invasion, utilizing the newly formed vascular tree as a route for metastization at different organs (Figure 2).

\section{Pro- and anti-angiogenesis treatment: from here to where?}

During the last two decades, an explosive interest in angiogenesis research has generated the indispensable insights to develop the first clinically approved antiangiogenic agents for cancer and blindness. This novel treatment is likely to change the face of medicine in the next decade, as over 500 million people worldwide are estimated to benefit from pro- or anti-angiogenesis treatment.

The concept that angiogenesis is essential for tumor growth and metastasis, representing a necessary step in the control of cancer development, which could be regulated by pharmacological and/or genetic suppression of blood vessel growth, has engendered a long-standing interest in the identification of molecules or synthetic compounds that block angiogenesis ${ }^{(20)}$. Anti-angiogenesis therapy has been appealing for cancer treatment for three major reasons: i) it is possible that most tumors are dependent on angiogenesis, thereby providing a common target in the treatment of widely heterogeneous disease; ii) ECs are considered to be less likely to develop adaptations to bypass drug effects; iii) it is anticipated that tumor vessels are proliferative, therefore providing a differential target than the quiescent vessels present in normal tissues.

In the context of either anti-angiogenesis (to block vessel growth) or pro-angiogenic (to enhance vessel growth) therapies, VEGF and VEGF receptors seem to be a case of experimental and clinical success. Bevacizumab (avastin) (17, 75), Bay 43-9006 (sorafenib), and SU 11248 (sunitinib) are some of the antivascular agents in clinical development already approved by the United States Food and Drug Administration (FDA) for cancer treatment. Bevacizumab, a humanized monoclonal antibody against VEGF, when used with chemotherapy in metastatic colorectal cancer patients, demonstrated a prolonged overall survival ${ }^{(23)}$. In subsequent phase III trials, bevacizumab in combination with standard chemotherapy improved overall survival in lung and progression-free survival in breast cancer patients $^{(25)}$. It has also been reported to be active in patients with metastatic renal-cell cancer as monotherapy ${ }^{(73)}$. Further clinical success was recently obtained with broad-spectrum

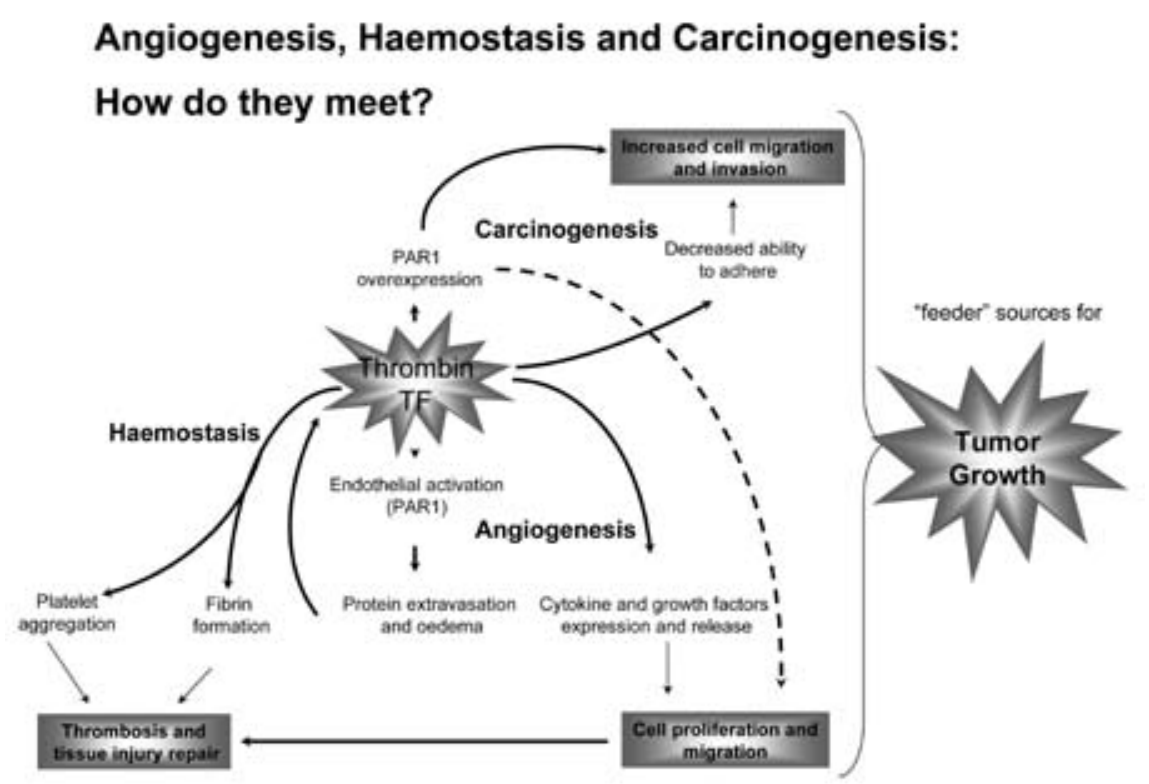

Figure 2 - The central actions of thrombin as mediator of blood coagulation cascade, angiogenesis and carcinogenesis. Thrombin is a multifunctional serine protease generated at a site of vascular injury, being the most effective agonist for platelet aggregation and activation. Thrombin also elicits a host of responses in the vascular endothelium, including shape and permeability changes, mobilization of adhesive molecules, and stimulation of different cytokines and growth factors, which when deregulated can promote the angiogenic switch leading to an exaggerated neovascularization, frequently detected in several tumours. Thrombin is also able to activate endothelial PAR1, which is known to be up-regulated in different tumours types. Therefore, all these evidences suggest that during the process of tumour growth, angiogenesis as well as haemostasis can serve as "feeder" sources for the tumour cells, underlying a close relationship among them 
multitargeted agents who target VEGF receptors and other tyrosine kinases present in endothelial and cancer cells. Phase III trials have demonstrated the efficacy of SU 11248 (sunitinib [targeting VEGFR1, 2, PDGF receptor, and c-Kit]) and Bay 43-9006 (sorafenib [targeting VEGFR2, 3, PDGFR, RET, C-Kit and Raf]) in the treatment of patients with renal cancer ${ }^{(25)}$. Based on these results sunitinib and sorafenib are now approved by the Food and Drug Administration (FDA) as monotherapies for kidney cancer. The clinical success of bevacizumab, sunitinib, and sorafenib as novel medicines for treatment of cancer patients has confirmed the relevance of angiogenesis research and has stimulated the search for novel and more effective anti-angiogenic approaches.

However, it is important to notice that some clinical trials designed to test anti-angiogenic therapy have met variable and rather disappointing success. In particular, not all tumor vessels appear equally susceptible to a single modality of anti-angiogenic therapy. There are many reasons for this type of response. For example, the participation of tumor cells in the vascular wall ("vascular mimicry") has been demonstrated in uveal carcinoma, and more recently in melanoma ${ }^{(21)}$. How responsive are these cells to anti-angiogenic therapy? The molecular nature of tumor microvessels appears to be more variable than anticipated, and differences in the tumor microenvironment are likely to influence therapeutic outcome. Although some antivascular agents have demonstrated activity as monotherapies, most human trials to date indicate that they are most effective when combined with conventional antitumor strategies ${ }^{(25,29)}$.

\section{Anticoagulant therapy: would it mean less angiogenesis and a better tumor survival outcome?}

In the nearly 135 years since Trousseau first described migratory thrombophlebitis in cancer patients, thromboembolism has become a well-established presenting sign and complication of cancer ${ }^{(64)}$. Indeed, two large epidemiological studies involving 86,000 patients with thromboembolism, 4,200 of which had cancer, suggest that the risk of deep vein thrombosis or pulmonary thromboembolism is 3.2 times higher in cancer patients ${ }^{(37)}$. On the other hand, the risk of thrombosis is increasing with anti-neoplastic treatment, most probably due to cytotoxic damages within the endothelium, which then releases procoagulant substances and cytokines, responsible for blood coagulation activation. As results of these findings, anti-thrombotic therapy is considered a rational approach to prevent thromboembolism in cancer patients. Interestingly, as we will discuss next, effective antithrombin therapy seems to reduce the risk of cancer progression and even prolongs overall survival. The coagulation system is activated in cancer and is further amplified by treatment with chemotherapy, radiation or surgery. Hypercoagulation is documented in virtually all cancer types, albeit at different rates, and is the second leading cause of death in cancer patients. The relationship between clotting activation and carcinogenesis supports the view of cancer as a hypercoagulable state and holds implications for the development of thrombosis, enhancement of tumor growth and risk of poor clinical outcomes. Although it is well recognized that cancer can activate the coagulation cascade, it is less well-known that activation of the coagulation system may also support tumor progression, and more specifically tumor angiogenesis. Additionally, platelet activation in cancer patients and its impact on tumor progression and metastasis further expand the role of the haemostatic system in malignancy. The problem of thrombosis in patients with metastatic diseases is a serious concern for clinicians. Warfarin and unfractionated heparin are effective anticoagulants which have been used in clinical practice for more than 50 years. However, their use is associated with some concerns, including the need for intensive coagulation monitoring, wide variation in dose-response relationships, multiple drug interactions (in the case of warfarin), and serious immune-mediated thrombocytopenia (in the case of heparin). The introduction of low-molecular-weight heparin (LMWH) improved the anticoagulation therapy by enhancing efficacy and eliminating the need for intensive coagulation monitoring. An important role has been demonstrated for LMWH (tinzaparin), warfarin, anti-factor Vlla, and recombinant TF pathway inhibitor in the regulation of angiogenesis, tumor growth and tumor metastasis ${ }^{(42)}$. Fondaparinux, the first selective factor Xa inhibitor, represents another improvement in anticoagulation therapy. By binding rapidly and strongly to antithrombin, its sole physiologic target in plasma, fondaparinux catalyzes specifically the inhibition of factor $\mathrm{Xa}$, which results in effective and linear dose-dependent inhibition of thrombin generation ${ }^{(43)}$. Additionally, efficient inhibition of factor $\mathrm{Xa}$ activity impairs the activation of TF/factor VIla complex leading to downregulation of procoagulant state, pro-angiogenesis, and proinflammatory factors induced by TF/factor VIIa ${ }^{(43)}$. Furthermore, a number of orally active direct antithrombin and anti-factor $\mathrm{Xa}$ are in advanced clinical development 
for various thromboembolic disorders. In the future, they might also be used as part of an anti-angiogenic therapy, to block vessel growth.

\section{Perspectives}

Undoubtedly a comprehensive compendium of angiogenic regulation is still to be written. Despite the exceptionally increasing informative data accumulated in recent years, and the development of new methodological options for molecular investigation, we still have several unsolved issues to be elucidated. Recent years have been motivating in this field especially because basic research is now integrated to clinical-pathological setting. New questions and answers are gradually emerging in the context of daily routine practice.

Knowledge of blood coagulation cascade players in angiogenesis opens a new avenue for research with a perspective to join anti-coagulant therapies into the armamentarium of anti-angiogenesis and anti-cancer strategies.

\section{References}

1. BASSUS, S. O. et al. Thrombin causes vascular endothelial growth factor expression in vascular smooth muscle cells: role of reactive oxygen species. Arterioscler Thromb Vasc Biol, v. 21, p. 1550-5, 2001.

2. BERGERS, G. A. B. Tumorigenesis and the angiogenic switch. Nat Rev, v. 3, p. 401-10, 2002.

3. CAO, H.; DRONADULA, N.; RAO, G. N. Thrombin induces expression of FGF-2 via activation of PI3K-Akt-Fra-1 signaling axis leading to DNA synthesis and motility in vascular smooth muscle cells. Am J Physiol Cell Physiol, v. 290, p. C172-82, 2006.

4. CARMELIET, P. Mechanisms of angiogenesis and arteriogenesis. Nat Med, v. 6, p. 389-95, 2000.

5. CARMELIET, P. et al. Abnormal blood vessel development and lethality in embryos lacking a single VEGF allele. Nature, v. 380, p. 435-9, 1996.

6. CUCINA, A. L. et al. Autocrine production of basic fibroblast growth factor translated from novel synthesized mRNA mediates thrombin-induced mitogenesis in smooth muscle cells. Cell Biochem Funct, v. 20, p. 39-46, 2002.

7. DANIEL, G. V. et al. Thrombin stimulates c-sis gene expression in microvascular endothelial cells. J Biol Chem, v. 261, p. 9579-82, 1986.

8. DARMOUL, D. et al. Activation of proteinase-activated receptor 1 promotes human colon cancer proliferation through epidermal growth factor receptor transactivation. Mol Cancer Res, v. 2, p. 514-22, 2004.

9. DAVIS, S. et al. Isolation of angiopoietin-1, a ligand for the TIE2 receptor, by secretion-trap expression cloning. Cell, v. 87, p. 1161-9, 1996.

10. DUARTE, M. et al. Thrombin induces rapid PAR1-mediated non-classical FGF1 release. Biochem Biophys Res Commun, v. 350, p. 604-9, 2006.

11. ESSER, S. K. et al. Vascular endothelial growth factor induces endothelial fenestrations in vitro. J Cell Biol, v. 140, p. 947-59, 1998.

12. EVEN-RAM, S. B. et al. Thrombin receptor overexpression in malignant and physiological invasion processes. Nat Med, v. 4, p. 909-14, 1998.
13. FERRARA, N. et al. Heterozygous embryonic lethality induced by targeted inactivation of the VEGF gene. Nature, v. 380, p. 439-42, 1996.

14. FERRARA, N. et al. Pituitary follicular cells secrete a novel heparin-binding growth factor specific for vascular endothelial cells. Biochem Biophys Res Commun, v. 161, p. 851-8, 1989.

15. FISCHER, E. G.; RUF, W.; MUELLER, B. M. Tissue factorinitiated thrombin generation activates the signaling thrombin receptor on malignant melanoma cells. Cancer Res, v. 55, p. 1629-32, 1995.

16. FOLKMAN, J. Angiogenesis in cancer, vascular, rheumatoid and other disease. Nat Med, v. 1, p. 27-31, 1995.

17. GERBER, H. P.; FERRARA, N. Pharmacology and pharmacodynamics of bevacizumab as monotherapy or in combination with cytotoxic therapy in preclinical studies. Cancer Res, v. 65, p. 671-80, 2005.

18. GERBER, H. P. et al. VEGF is required for growth and survival in neonatal mice. Development, v. 126, p. 1149-59, 1999.

19. GOOD, D. J. et al. A tumor suppressor-dependent inhibitor of angiogenesis is immunologically and functionally indistinguishable from a fragment of thrombospondin. Proc Natl Acad Sci USA, v. 87, p. 6624-8, 1990.

20. HANAHAN, D. F. J. Patterns and emerging mechanisms of the angiogenic switch during tumorigenesis. Cell, v. 86, p. 353-64, 1996.

21. HENDRIX, M. J. et al. Remodeling of the microenvironment by aggressive melanoma tumor cells. Ann NY Acad Sci, v. 995, p. 151-61, 2003.

22. HEROULT, M.; SCHAFFNER, F.; AUGUSTIN, H. G. Eph receptor and ephrin ligand-mediated interactions during angiogenesis and tumor progression. Exp Cell Res, v. 312, p. 642-50, 2006.

23. HURWITZ, H. et al. Bevacizumab plus irinotecan, fluorouracil, and leucovorin for metastatic colorectal cancer. N Engl J Med, v. 350, p. 2335-42, 2004.

24. ITOH, N.; ORNITZ, D. M. Evolution of the Fgf and Fgfr gene families. Trends Genet, v. 20, p. 563-9, 2004.

25. JAIN, R. K. et al. Lessons from phase III clinical trials on 
anti-VEGF therapy for cancer. Nat Clin Pract Oncol, v. 3, p. 24-40, 2006.

26. KABRUN, N. et al. Flk-1 expression defines a population of early embryonic hematopoietic precursors. Development, v. 124, p. 2039-48, 1997.

27. KAMPHAUS, G. D. et al. Canstatin, a novel matrix-derived inhibitor of angiogenesis and tumor growth. J Biol Chem, v. 275, p. 1209-15, 2000.

28. KAUSHAL, V. et al. Thrombin receptor expression is upregulated in prostate cancer. Prostate, v. 66, p. 273-82, 2006.

29. KERBEL, R. S. Antiangiogenic therapy: a universal chemosensitization strategy for cancer? Science, v. 312, p. 1171-5, 2006.

30. LEE, S. H.; SCHLOSS, H. D.; SWAIN, J. L. Maintenance of vascular integrity in the embryo requires signaling through the fibroblast growth factor receptor. J Biol Chem, v. 275, p. 33679-87, 2000.

31. LEUNG, D. W. et al. Vascular endothelial growth factor is a secreted angiogenic mitogen. Science, v. 246, p. 1306-9, 1989.

32. LOPEZ-PEDRERA, C. et al. Tissue factor as an effector of angiogenesis and tumor progression in hematological malignancies. Leukemia, v. 20, p. 1331-40, 2006.

33. MACIAG, T. et al. Heparin binds endothelial cell growth factor, the principal endothelial cell mitogen in bovine brain. Science, v. 225, p. 932-5, 1984.

34. MAESHIMA, Y.; COLORADO, P. C.; KALLURI, R. Two RGD-independent alpha vbeta 3 integrin binding sites on tumstatin regulate distinct anti-tumor properties. J Biol Chem, v. 275, p. 23745-50, 2000.

35. MAIONE, T. E. et al. Inhibition of angiogenesis by recombinant human platelet factor-4 and related peptides. Science, v. 247, p. 77-9, 1990.

36. MAISONPIERRE, P. C. et al. Angiopoietin-2, a natural antagonist for Tie2 that disrupts in vivo angiogenesis. Science, v. 277, p. 55-60, 1997.

37. MARAGOUDAKIS, M. E.; TSOPANOGLOU, N. E. On the mechanism(s) of thrombin-induced angiogenesis. Adv Exp Med Biol, v. 476, p. 47-55, 2000.

38. MIGNATTI, P.; RIFKIN, D. B. Nonenzymatic interactions between proteinases and the cell surface: novel roles in normal and malignant cell physiology. Adv Cancer Res, v.78, p. 103-57, 2000.

39. MILLAUER, B. et al. High affinity VEGF binding and developmental expression suggest Flk-1 as a major regulator of vasculogenesis and angiogenesis. Cell, v. 72, p. 835-46, 1993.

40. MOLDOVAN, N. I.; ASAHARA, T. Role of blood mononuclear cells in recanalization and vascularization of thrombi: past, present, and future. Trends Cardiovasc Med, v. 13, p. 265-69, 2003.

41. MOSER, T. L. et al. Angiostatin binds ATP synthase on the surface of human endothelial cells. Proc Natl Acad Sci USA, v. 96, p. 2811-16, 1999.

42. MOUSA, S. A. Anticoagulants in thrombosis and cancer: the missing link. Semin Thromb Hemost, v. 28, p. 4552, 2002.

43. MOUSA, S. A. Role of current and emerging antithrombotics in thrombosis and cancer. Timely Top Med Cardiovasc Dis, v. 10, p. E19, 2006.
44. NEUFELD, G. et al. The neuropilins: multifunctional semaphorin and VEGF receptors that modulate axon guidance and angiogenesis. Trends Cardiovasc Med, v. 12, p. 13-9, 2002.

45. NICKOLOFF, B. J. Characterization of lymphocytedependent angiogenesis using a SCID mouse: human skin model of psoriasis. J Invest Dermatol Symp Proc, v. 5 , p. 67-73, 2000.

46. NYBERG, P.; XIE, L.; KALLURI, R. Endogenous inhibitors of angiogenesis. Cancer Res, v. 65, p. 3967-79, 2005.

47. O'REILLY, M. S. et al. Endostatin: an endogenous inhibitor of angiogenesis and tumor growth. Cell, v. 88, p. 277 85, 1997.

48. O'REILLY, M. S. et al. Angiostatin: a novel angiogenesis inhibitor that mediates the suppression of metastases by a Lewis lung carcinoma. Cell, v. 79, p. 315-28, 1994.

49. $\mathrm{OH}, \mathrm{H}$. et al. Hypoxia and vascular endothelial growth factor selectively up-regulate angiopoietin-2 in bovine microvascular endothelial cells. J Biol Chem, v. 274, p. 15732-9, 1999.

50. ORNITZ, D. M.; ITOH, N. Fibroblast growth factors. Genome Biol, v. 2, p. 1-12, 2001.

51. PANETTI, T. S. Differential effects of sphingosine 1 phosphate and lysophosphatidic acid on endothelial cells. Biochim Biophys Acta, v 1582, p. 190-96, 2002.

52. PETTERSSON, A. et al. Heterogeneity of the angiogenic response induced in different normal adult tissues by vascular permeability factor/vascular endothelial growth factor. Lab Invest, v. 80, p. 99-115, 2000.

53. PLOUET, J.; SCHILLING, J.; GOSPODAROWICZ, D. Isolation and characterization of a newly identified endothelial cell mitogen produced by AtT20 cells. EMBO J, v. 8, p. 3801-7, 1989.

54. RAK, J. et al. Oncogenes and angiogenesis: signaling three-dimensional tumor growth. J Invest Dermatol Symp Proc, v. 5, p. 24-33, 2000.

55. RIBATTI, D. et al. Human recombinant interferon alpha$2 a$ inhibits angiogenesis of chick area vasculosa in shell-less culture. Int J Microcirc Clin Exp, v 16, p. 165-9, 1996.

56. RIBATTI, D.; VACCA, A.; PRESTA, M. The discovery of angiogenic factors: a historical review. Gen Pharm, v. 35, p. 227-231, 2002.

57. SELLKE, F. W. et al. Angiogenesis induced by acidic fibroblast growth factor as an alternative method of revascularization for chronic myocardial ischemia. Surgery, v. 120, p. 182-8, 1996.

58. SENGER, D. R. et al. Tumor cells secrete a vascular permeability factor that promotes accumulation of ascites fluid. Science, v. 219, p. 983-5, 1983.

59. SHING, Y. et al. Heparin-affinity: purification of a tumorderived capillary endothelial cell growth factor. Science, v. 223, p. 1296-8, 1984.

60. SPIEGEL, S.; MILSTIEN, S. Sphingosine 1-phosphate, a key cell signaling molecule. J Biol Chem, v. 277, p. 25851-4, 2002.

61. STANDKER, L. et al. Isolation and characterization of the circulating form of human endostatin. FEBS Lett, v. 420, p. 129-33, 1997.

62. TARZAMI, S. T. et al. Thrombin and PAR-1 stimulate 
differentiation of bone marrow-derived endothelial progenitor cells. J Thromb Haemost, v. 4, p. 656-63, 2006.

63. THURSTON, G. et al. Angiopoietin-1 protects the adult vasculature against plasma leakage. Nat Med, v. 6, p. 460-3, 2000.

64. TROUSSEAU, A. P. Phlegmasia alba dolens. In: Clinique Medicale de l'Hotel-Dieu de Paris. Paris: JB Balliere et Fils. p. 654-712, 1865.

65. TSOPANOGLOU, N. E.; MARAGOUDAKIS, M. E. On the mechanism of thrombin-induced angiogenesis: inhibition of attachment of endothelial cells on basement membrane components. Angiogenesis, v 1 , p. 192-200, 1998.

66. VU, T. K. et al. Molecular cloning of a functional thrombin receptor reveals a novel proteolytic mechanism of receptor activation. Cell, v. 64, p. 1057-68, 1991.

67. WAKEFIELD, T. W. et al. Neovascularization during venous thrombosis organization: a preliminary study. J Vasc Surg, v. 30, p. 885-92, 1999.

68. WERNERT, N. et al. The Ets 1 transcription factor is upregulated during inflammatory angiogenesis in rheumatoid arthritis. J Mol Med, v. 80, p. 258-66, 2002.
69. XIAN, W.; SCHWERTFEGER, K. L.; ROSEN, J. M. Distinct roles of FGFR1 and FGFR2 in regulating cell survival and epithelial-mesenchymal transition. Mol Endocrinol, 2007 (in press).

70. YAMAGUCHI, T. P. et al. flk-1, an flt-related receptor tyrosine kinase is an early marker for endothelial cell precursors. Development, v. 118, p. 489-98, 1993.

71. YAMAGUCHI, T. P. et al. fgfr-1 is required for embryonic growth and mesodermal patterning during mouse gastrulation. Genes Dev, v. 8, p. 3032-44, 1994.

72. YAMASHITA, J. et al. Flk1-positive cells derived from embryonic stem cells serve as vascular progenitors. Nature, v. 408, p. 92-6, 2000.

73. YANG, J. C. et al. A randomized trial of bevacizumab, an anti-vascular endothelial growth factor antibody, for metastatic renal cancer. N Engl J Med, v. 349, p. 427-34, 2003.

74. ZIEGLER, B. L. et al. KDR receptor: a key marker defining hematopoietic stem cells. Science, v. 285, p. 1553-8, 1999.

75. ZONDOR, S. D.; MEDINA, P. J. Bevacizumab: an angiogenesis inhibitor with efficacy in colorectal and other malignancies. Ann Pharmacother, v. 38, p. 1258-64, 2004. 